\title{
ARTICLES \\ What Shall We Eat? An Ethical Framework for Well-Grounded Food Choices
}

\author{
Anna T. Höglund ${ }^{1}$ (D)
}

Accepted: 19 February 2020 / Published online: 5 March 2020

(c) The Author(s) 2020

\begin{abstract}
In production and consumption of food, several ethical values are at stake for different affected parties and value conflicts in relation to food choices are frequent. The aim of this article was to present an ethical framework for well-grounded decisions on production and consumption of food, guided by the following questions: Which are the affected parties in relation to production and consumption of food? What ethical values are at stake for these parties? How can conflicts between the identified values be handled from different ethical perspectives? Four affected parties, relevant for both production and consumption of food, were identified, namely animals, nature, producers and consumers. Working form a bottom-up perspective, several values for these parties were identified and discussed. For animals: welfare, not being exposed to pain and natural behavior; for nature: low negative impact on the environment and sustainable climate; for producers: fair salaries and safe working conditions; and for consumers: access to food, autonomy, health and food as part of a good life. As several of these values can come into conflict when choices of what to eat should be made, the article argues for the need of weighing values from four different perspectives in food ethics dilemmas, namely duties, consequences, virtues and care. The suggested ethical framework can provide moral guidance to both producers of food and to consumers in a supermarket. Thereby, it can contribute to more well-grounded decisions concerning what to eat and make people feel a little bit more secure when reflecting over the question: What shall we eat?
\end{abstract}

Keywords Food ethics $\cdot$ Affected parties $\cdot$ Values $\cdot$ Value conflicts $\cdot$ Ethical framework

Anna T. Höglund

anna.hoglund@crb.uu.se

1 Centre for Research Ethics and Bioethics, Department of Public Health and Caring Sciences,

Uppsala University, Box 564, 75122 Uppsala, Sweden 


\section{Introduction}

To reflect ethically over what we eat has been part of Western culture for centuries. In his comprehensive exposé over Western food ethics, Zwart (2000) showed how dietetics was a prominent part already of the ethics in ancient Greece. For example, Plato reasoned over the place of food in human life in his book The Republic. He argued that food in itself was not a pleasure, although easily mistaken for such. Rather, Plato argued, it was the removal of pain in the form of hunger that was a pleasure, not food in itself (Plato 1955). Aristotle emphasized temperance in relation to food. Hence, dietetics was a central part of his ethics, where virtues and vices were at the fore. Aristotle's position was that gluttony was a vice that should be avoided, whereas the virtue of temperance was what should be strived for and developed (Aristotle 1980).

Regulations around food are also common in the Old Testament. The distinction between allowed and not allowed food is central in the Hebrew Bible. For example, in Deuteronomy 14:3-7, it says that a Jew must not eat meat from animals that have cloven hoofs. In contrast to this, the New Testament does not include similar passages on legitimate and illicit food. On the contrary, in Matthew 15:11-17, Jesus proclaims that his followers should not be anxious about food or drink. Rather, food in the New Testament is a symbol of something sacred-as food should be blessed before intake - and of fellowship and solidarity, as for example signified in the Holy Communion.

During the middle ages, food ethics was predominantly elaborated within monastic contexts. Now, abstention from food intake became desirable. The mortification of the flesh was seen as a form of withdrawal from the sinful world. Through fasting, monks and nuns could distinguish themselves from the laity (Zwart 2000). However, Martin Luther, in his Table Talk, argued against this and instead recommended food as a remedy for melancholy and various temptations, if consumed in large quantities (Luther 2015).

In modern times, a scientific view dominated in food ethics. Further, the social dimension of food evolved, for example through the view that food intake could be a way of expressing your personality. Hence, vegetarianism became more common in the nineteenth century. Apart from this, the scientific view during modernity included attention to famine and injustice in the global distribution of food (Zwart 2000).

Whereas pre-modern food ethics mainly focused on aspects related to the consumption of food, today's food ethics is more focused on the production of food. Therefore, topics such as animal ethics and ethical conflicts related to gene modified (GM) products have been well developed within the field. However, I argue that contemporary food ethics need also to include aspects of the meal, as what we eat can have social and cultural meaning (Tellström 2015; Höglund 2019).

In the introduction to his book The Ethics of Food, Gregory Pence states that "food makes philosophers of us all" (Pence 2002, p. 6). By that he supposedly means that questions of what we eat tend to engage people and almost everyone has opinions about what is the "right" diet or type of food that should be served. 
Despite this, food ethics in its contemporary form did not emerge as a separate field in applied ethics until the 1990s. Often, Ben Mepham's book Food Ethics from 1996 is mentioned as a starting point for this. For example, Zwart writes:

With the recent publication of the volume Food Ethics by Ben Mepham in 1996, a new branch of applied or professional ethics was introduced, but a long tradition of dietetics and other forms of moral concern with food preceded it. (Zwart 2000, p. 114).

Zwart further points out, that it was in the late 1990s that this particular branch of applied ethics received its current label: "food ethics" (Zwart 2000).

In my book Vad ska vi äta? (What Shall We Eat?) from 2019, I observe that the debate on food and what we should eat often lacks a thorough ethical analysis (Höglund 2019). One explanation put forward in the book is that we might think that we have an ethical debate on producing and consuming food, as aspects of the environment, sustainability, climate change and animal welfare are included in the discussion, when in fact we are only discussing one issue at the time, without relating different values to each other. Nota bene: I do not claim that sustainability or animal welfare are not ethically relevant aspects-because they are-but I do claim that the debate on food production in many Western countries lacks a thorough ethical analysis, where different moral values are weighed against each other from different ethical perspectives. Further, I argue, that we need to include also the consumption of food in our ethical debates, as was the case in pre-modern food ethics, as described above.

Against this background, the aim of this article is to present an ethical framework for well-grounded ethical decisions regarding production and consumption of food. The investigation is guided by the following questions:

- Which are the affected parties in relation to production and consumption of food?

- What ethical values are at stake for these parties?

- How can conflicts between the identified values be handled from different ethical perspectives?

\section{A Matrix for Food Ethics}

In his book Food Ethics, Ben Mepham (1996) suggested a matrix for an ethical analysis of food biotechnologies. The matrix starts out from a principled approach to ethics, building on Beauchamp's and Childress' well-known four principles, originally developed as prima facie obligations for health-care workers, namely autonomy, justice, non-maleficence and beneficence (Beauchamp and Childress 2009). With the attempt to apply these principles on food production, Mepham starts by identifying affected parties or interest groups in relation to the production of food. He admits that this is a complicated issue, in comparison to, 
for example, medical ethics where often one party is significantly affected by ethical decisions, namely the patient. But in relation to food the situation is different:

In food production, typically, millions of people (including producers, processors, retailers and consumers), the physical and biological environments and, often, non-human animals, are liable to be affected, one way or another, by decisions on a new technology (Mepham 1996, p. 105).

Based on this, the affected parties Mepham identifies in his matrix of food ethics are the treated organism, the producers (e.g., farmers), the consumers and biota, defined as the animal and plant life of a region. He also adapts the ethical principles he has chosen so that they are meaningful to the identified interest groups. As the principles of non-maleficence and beneficence are "reciprocally related" (Mepham 1996, p. 106) he chooses to combine them into "the principle of respect for well-being". Apart from that, his matrix includes the principles of autonomy and justice.

Mephan argues that these ethical principles are important in various ways to the affected parties he has identified. For example, well-being for the treated organism is animal welfare. For the producers well-being means adequate income and good working conditions and for consumers it means availability of safe and healthy food. A simplified version of Mepham's matrix is described in Table 1.

I find Mepham's matrix interesting, but also limited. Primarily, I argue that his analysis suffers from only including three ethical principles which are applied on four affected parties and thereby being developed from a top-down perspective. Second, it is limited through its focus on food biotechnologies. Thereby it is primarily relevant for the production of food, leaving several other aspects of food ethics ignored. Therefore-although inspired by Mepham-I have developed a somewhat different framework for food ethics, which I will describe in the following section. My analysis is made from a bottom-up approach and with a broader perspective, including both production and consumption of food.

\section{Affected Parties and Values in Food Ethics}

In agreement with Mepham, I argue that there are several affected parties in relation to food and that an ethical analysis needs to consider all these. In order to cover the ethics of both production and consumption of food, I have identified the following affected parties: animals, nature, producers and consumers. The first three are relevant for the production of food, as various producers make food from animals or plants, whereas the last one, consumers, is relevant for the consumption of food. But, instead of taking a top-down approach and doing an analysis from in advance chosen ethical principles, I intend to identify ethical values that can be at stake for these affected parties, building on the literature in the field, and discuss in what way these values are relevant for the different parties; thereby pursuing a more bottom-up approach.

I choose to label all aspects I discuss as "values", well aware that they in the literature are also often described as principles. I choose "values", though, as my attempt is to discuss how the identified aspects can be valuable for the different 
Table 1 Simplified description of Mepham's (1996, p. 106) matrix for an ethical analysis of food biotechnologies

\begin{tabular}{|c|c|c|c|c|}
\hline & Organism & Producer & Consumer & Biota \\
\hline Autonomy & $\begin{array}{l}\text { Behavioral free- } \\
\text { dom }\end{array}$ & $\begin{array}{l}\text { Freedom to adopt or } \\
\text { not }\end{array}$ & Free choice & $\begin{array}{l}\text { Maintenance of biodi- } \\
\text { versity }\end{array}$ \\
\hline Well-being & Animal welfare & $\begin{array}{l}\text { Income, working } \\
\text { conditions }\end{array}$ & Availability, safety & $\begin{array}{l}\text { Conservation of ani- } \\
\text { mal and plant life }\end{array}$ \\
\hline Justice & Respect for telos & Fair treatment & $\begin{array}{l}\text { Universal afford- } \\
\text { ability }\end{array}$ & Sustainability \\
\hline
\end{tabular}

affected parties. The affected parties are not always moral subjects why it can be discussed whether, for example, nature can be an affected party as it cannot in itself have interests. However, for the sake of the argument, I have decided to treat all affected parties in the same way, seeking ethical values in relation to them that can be at stake in production or consumption of food.

The values I identify and discuss in the following build on previous research. Hence, my presentation summarizes a long history of deliberation concerning food ethics. I do claim, however, that my investigation sheds new light on these questions, particularly through the bottom-up approach and the ethical analysis I pursue in the last section of the article.

Hence, in the following, I will go through relevant ethical values for the affected parties animals, nature, producers and consumers.

\section{Animals}

To eat or not eat meat from animals might be to most heatedly debated question within food ethics. The arguments pro eating meat concern, for example, humans' need for protein and other nutrients and that meat can be a source of that. Another argument is that people may think that meat tastes good and therefore choose to eat it. Apart from that, arguments justifying meat eating might also be that meat is suitable to humans, depending on the form of our teeth, the way we take up nutrients and what kind of food our body can handle (see e.g. Singer 2002). Finally, it can be argued, that for countries with cold climate-such as the Nordic countries-meat production was historically necessary for sufficient food production, as the cultivating of vegetables in large scale during the whole year was not possible in this part of the world. Today, breeding for meat production can be equally important in times of crisis. The Swedish agronomists Kersti Linderholm and Lennart Wikström argue:

People cannot eat grass, but ruminants can, and they transform the grass to nutritious food, like milk and meat. This has been a prerequisite for people to survive in the Swedish climate (Linderholm \& Wikström 2019).

However, the ethical arguments contra meat eating are several, often based on values that are at stake for the animals. I will briefly go through some of them. 
First, an important value for the affected party animals is that they should not be exposed to pain. This has been argued for by, among others, Singer and Mason (2007). They base their conclusions on a preference utilitarian arguing, where a basic assumption is that if a living being is capable to experience pain it has moral interests. A moral imperative is thus to act so that such living beings are not exposed to pain (Singer and Mason 2007).

A similar position is held by the philosopher Richard Ryder, who coined the concept "painism" (Ryder 2001). His arguing is based on rights, not interests and preferences as was the case for Singer and Mason. According to Ryder, living beings who can experience pain have intrinsic value. This means that they may not be used only as means to an end, but must always also be treated as ends in themselves. Thereby, they have a right to not being exposed to pain, according to this reasoning.

Another value for animals in food production is their right to natural behavior. However, this is a contested concept. The Swedish philosopher Pär Segerdahl has argued that it is not possible to separate domestic animals, such as cows, pigs or hens, from the context where they are bred. Hence, these animals have for centuries adopted to people and a domestic life. So, what is "natural" for such livestock, Segerdahl asks (Segerdahl 2009). This is an intriguing question. However, the Swedish law regarding protection of animals (Prop. 2017/18:147) states that natural behavior is behavior that domestic animals are highly motivated to and that is appropriate for their need for space, activity, rest and social context. Based on such a definition it is possible to argue that also the right to natural behavior is an important value for animals as an affected party in food ethics.

The right not to be exposed to pain as well as the right to natural behavior can both be seen as aspects of animal welfare. So, to sum up, the values that are at stake for the affected parties animals are welfare in the form of not being exposed to pain and possibilities to natural behavior.

\section{Nature}

For the second affected party in the presented food ethics analysis-nature-there are primarily two values that have been discussed in the literature; namely low negative impact on the environment and a sustainable climate. These two aspects are related, but can also be separated. Factory farming of animals for food production can violate the animals' right to welfare, which has been discussed above, but it can also affect the environment in many ways. For example, large-scale factory farming can pollute the surrounding environment through emissions and use of energy from non-renewable resources (Singer and Mason 2007; Mepham 1996). Likewise, fish breeding can contribute to the pollution of seas, for example by toxins in the fish feed (Lövin 2010; Singer 2002).

Concerning sustainability and climate changes, it is today well established that breeding of cows and pigs give rise to high levels of $\mathrm{CO}_{2}$, which in turn can aggravate the climate change (Röös 2012). Apart from these direct influences, also transports of different kind need to be taken into account when analyzing environmental effects of production and consumption of food (Röös 2012). Transports by 
car or plane give rise to high levels of $\mathrm{CO}_{2}$ and can come from both retailers and consumers.

\section{Producers}

The third affected party in the analysis are the producers of food. They can of course be of many kind, from big factories to small farmers. The values that can be at stake for food producers are quite similar, though, be they small or big, namely fair salaries and safe working conditions. Apart from that, all producers of food have an interest in making profit on their production, otherwise the production cannot continue. The ethical value, however, should not be profit but rather cost effectiveness, namely that resources are used efficiently and for relevant purposes (Höglund 2019, p. 107).

Research has shown that work in animal factories can be both dangerous and underpaid (Singer 2002). Further, in countries with low salaries, often used as trading partners by industrial countries in order to cut prices, working conditions in food production in general can be very bad. In addition, child labor can occur in these countries (Singer 2002). In such cases, important ethical demands based on the values of fair salaries and safe working conditions are not fulfilled. According to Singer and Mason (2007, p. 153), values related to producers of food can cause conflicts of interest between locally produced food and imported food. On the one hand, we might have an interest in supporting local farmers or industries. On the other, we might feel morally obliged to support farmers in developing countries by purchasing their products-provided that important ethical demands are fulfilled in their food production.

\section{Consumers}

Finally, we have the consumers, that is, we who should eat the food. According to Coff (2006, p. 78), a consumer is the person who consumes something that someone else has produced. For consumers of food, four values can be identified, namely access to food, autonomy, health and a good life.

Access to food as a right for everyone is stated in the United Nations' Declaration of Human Rights. In Article 25 it says:

Everyone has the right to a standard of living adequate for the health and wellbeing of himself and his family, including food, clothing, housing and medical care and necessary social services.

In spite of this, access to food is not shared equally across the globe. In some parts of the world starvation is still a problem whereas in other areas obesity is the greatest challenge to public health. The duty to fulfill the right to food falls first and foremost on governments. However, one can claim that also individuals as citizens have a duty to support structures to meet the needs of the hungry (Telfer 1996). Access to 
food could also include work for social sustainability in a country, in order to secure food supply also in times of crisis (Linderholm and Wikström 2019).

When access to food is secured, the right to autonomy can be emphasized for the consumer. Often, this is interpreted as a freedom of choice for the individual (see e.g. Beauchamp and Childress 2009). In order to ensure this in relation to food, labelling has become more and more important, as disclosure of information about the available food is a presumption for consumer autonomy (Mepham 1996, p. 110). Another aspect of consumer autonomy, put forward by Mepham, is voluntariness. However, to ensure voluntariness in the choice of food is not always so straight forward. As the Swedish ethicist Helena Röcklinsberg has argued, the fact that a consumer buys a product in his or her grocery shop cannot be taken for granted to be a consent to buy that exact product. She writes:

Consent by purchase is an uncertain mirror of consumer preferences, since such patterns express choice between available products, rather than consent to what is available (Röcklinsberg 2006, p. 287).

Autonomy can be linked to the consumer's right to healthy food. Here the requirement for labels is increased, as it is through labelling the consumer can get information of, for example, how the vegetables are cultivated. Regulations that prevent too high levels of toxins in food are also of utmost importance in order to fulfil the consumer's right to healthy food.

Finally, one can state that in Western countries people spend more time and money on food than is needed to stay alive. Arguable, we do this because food gives us great pleasure. Hence, it is reasonable to argue that also well-being and food as a contribution to a good life are important values for the consumer. According to Elizabeth Telfer, to treat food as well-being is based on two rights for the individual: the right to safeguard one's own happiness and the right to lead a worthwhile life (Telfer 1996, p. 24). At first sight, these rights can be apprehended as opposites of the obligation mentioned above: to support structures to meet the needs of the hungry. However, in line with Telfer I argue, that these rights are compatible. Telfer writes:

In this book I have pointed out that for those of us who live in the first World, eating is usually not only a necessity but also a leisure activity, and I have claimed that we are justified in treating our food in this way. I have argued that we have real and extensive obligations to those who do not have enough to eat. But I have also claimed that we are entitled to aim at happiness and selffulfillment, and that what we eat and how we regard food has an important part to play in the pursuit of both these aims (Telfer 1996, p. 120).

In sum, for the affected party consumer the values at stake are access to food, autonomy, health and a good life. An overview of all identified affected parties and values is found in Table 2. 
Table 2 Overview of affected parties and identified values in the presented ethical framework

\begin{tabular}{ll}
\hline Affected parties & Values \\
\hline Animals & Welfare; not being exposed to pain; natural behavior \\
Nature & Low negative impact on the environment; sustainable climate \\
Producers & Fair salaries; safe working conditions \\
Consumers & Access to food; autonomy; health; a good life \\
\hline
\end{tabular}

\section{Value Conflicts and Ethical Dilemmas}

Apparently, several values for different affected parties are at stake in production and consumption of food. It is therefore not surprising that value conflicts occur frequently in food choices. For example, the value of low prices and producer profit can conflict with animal welfare. Organic farming can conflict with the goal of maximizing the harvest outcome and the value of climate sustainability can come into conflict with consumer autonomy. Et cetera, the list could be extended.

How are such value conflicts to be handled? I argue, that many of the identified value conflicts in relation to food can be interpreted as ethical dilemmas, where values of equal importance conflict and there are good reasons for preserving more than one of them. In such situations, a weighing of values from different ethical perspectives is necessary. In the following, I will illustrate how this can be done, from the perspective of four relevant and well-established ethical theories, namely deontology (or Kantian ethics), consequentialism (or utilitarianism), virtue (or Aristotelian) ethics and ethics of care.

The reasons for choosing these four perspectives are several. First, consequentialism and deontology are according to several text books the two principal contemporary theories of ethics (see e.g. Rachels 1993; Beauchamp and Childress 2009; Mepham 1996). Second, virtue ethics is by leading text books presented as the most pertinent alternative to these two grand theories (see e.g. Rachels 1993; Beauchamp and Childress 2009). Finally, apart from these three theoretical perspectives, I have chosen to investigate what a care ethics perspective can contribute to a food ethics analysis. In this case, I build on Held (2006), who has stated that the ethics of care can been seen as "a potential moral theory to be substituted for such dominant moral theories as Kantian ethics, utilitarianism, or Aristotelian virtue ethics" (Held 2006, p. 9). Thereby, I find it relevant to discuss ethical dilemmas in food ethics, caused by conflicts between the identified values for affected parties, from these four ethical perspectives.

\section{Duties}

A moral duty is something that we have to do, not because it gives the best consequences or because we like it, but because it is the right thing to do. This is based on characteristics of the action itself. Some actions are our duty to perform, as they 
are morally right in themselves, such as to tell the truth or respect other people's dignity. Such arguing is also called deontology, from the Greek word for duty, deon. As Immanuel Kant argued, we can judge an action as duty or not by the maxim behind the action (Kant 1996). Categorical "oughts", according to this reasoning, are derived from principles that every rational person would accept (Rachels 1993, p. 119). In Kant's words: "Act only according to that maxim by which you can at the same time will that it should become a universal law" (Kant 1996; quoted in Rachels 1993, p. 119). So, what duties can we have in relation to food ethics dilemmas?

According to Elizabeth Telfer, we have three kind of food duties, namely duties to others, to ourselves and to animals. Duties to other people contain primarily the requirement to help the hungry and to strive for justice in food distribution (Telfer 1996, p. 61). Apart from this, I argue that one duty towards others in relation to food is respect. This includes respect for what is offered to eat, but also respect for people's food choices and desires. Discussions on food tend to be emotional and value-laden, which can be avoided if the duty of respect is observed. Duties to other people could also include respect for future generations. Thereby, concerns about the environment and sustainability can be included in our food duties towards other people.

Duties towards ourselves are trickier, as it can be discussed whether we can have duties directed to ourselves (Telfer 1996, p. 65). In line with Telfer, I claim that we can, and that in relation to food it is reasonable to argue that such duties are to exercise our autonomy, to eat healthy and to promote our self-development. The duty to eat healthy can also be seen as a duty towards other people, as unhealthy eating can lead to increased demands on healthcare, which in turn can tear on our common resources.

Concerning duties towards animals, they relate to the values discussed above, namely that animals in food production must not be exposed to stress and pain, but rather be allowed well-being and a natural behavior. However, our duties could also be extended to include respect for the animals' right to life. Interpreted as such, the eating of meat becomes immoral. But, what if the duty to feed the hungry come into conflict with the moral demand of refraining from eating meat? In such situations, a hierarchy of duties is needed. In line with Elizabeth Telfer I argue, that our moral duties to other people come first in such situations, based on the Kantian principle of human dignity and respect for persons (Kant 1996). In Telfer's words:

The thesis that we have a duty to refrain from eating meat seems to me one of the most important moral issues concerning food, second in importance only to our duty to help the hungry (Telfer 1996, p. 61).

Telfer's position is thus that we should refrain from eating meat, as she emphasizes the duty to respect animals so strongly. Against this, one could argue, that eating meat must not imply general disrespect towards animals. If treated respectfully, animals could be used for food production, as long as the ethical demands for well-being and natural behavior are fulfilled. Further, humans and domesticated animals have a long history together and animal husbandry does not by definition exclude respect for animals. Further, domesticated 
animals - such as cows and sheep-contribute to an open landscape which can help preserve biodiversity. Hence, one can argue that there is a mutual interdependence between humans and domesticated animals that is also of ethical value. Thereby, deontologically grounded respect for animal welfare can imply eating meat, and only if the respect is extended beyond animal well-being to the animals' right to life, which seems to be the position Telfer holds, eating meat becomes immoral.

Apart from the three kind of food duties that Telfer has identified (to others, to ourselves and to animals), one can add that we can also have duties towards nature, as nature has been identified as an affected party in relation to food ethics. Duties to nature could of course overlap with duties to others, for example in the form of duties towards future generations, and to animals. But it is also possible to argue that we can have duties towards nature in itself, concerning for example the duty to preserve biodiversity.

\section{Consequences}

Apart from deontological aspects, also a consequentialist arguing can be a guiding perspective in some of the value conflicts and dilemmas that can occur in the production and consumption of food. In short, a consequentialist perspective means that an action is judged as moral or immoral based on its consequences. In the literature, such arguing is also called utilitarianism and derives from the theories developed by David Hume, Jeremy Bentham and John Stuart Mill. A basic assumption here is that morality is not a matter of following abstract rules, as was the case for Immanuel Kant, but of striving for as much happiness and utility as possible in the world. Therefore, our actions are judged as right or wrong depending on their consequences (Rachels 1993, pp. 90-91).

Reflections over our actions' consequences in relation to food are relevant when we, for example, consider whether to buy locally produced food or imported organic products. Through buying imported organic products, the consequences for the environment in the producing areas could be good, but at the same time, long transports could have affected the climate negatively. Further, the value of supporting local farmers and preserve an open landscape in our own country might be neglected when we buy imported food. Yet, another aspect that we might take into account from a consequentialist perspective concerns the possibility for a country to be self-sufficient with food in case of a crisis. From a consequentialist perspective, it is reasonable to hold that we from this perspective need to support our local food producers.

However, as in all consequence ethics, central questions to take into account from this perspective are: what consequences are we considering-the direct or the indirect ones? And for whom should the consequences be good? For myself and my close ones? Or for as many people as possible? And what about animals and the nature? In order to answer such questions, we need safe and correct information to build our decisions on. Unfortunately, this is not always the case when it comes to food. On the contrary, value-laden information is quite frequent in this area. 


\section{Virtues}

The ethics of virtue derives from Aristotle's thinking in his Nicomachean Ethics (launched around $325 \mathrm{BC}$ ). Here, the central question is not what actions we should perform, but what a good person is like. Morality, according to this position, is thus about character (Aristotle 1980). A moral virtue can be described as a character trait that can be learned and developed, based on experience and good role models. In our lives, we should strive for such moral virtues and we can identify them as the middle path between two extremes (vices) that should be avoided. For example, courage is a virtue, and the related vices to be avoided are cowardice and arrogance or hubris. Hence, virtue ethics is more focused on what sort of persons we are, than on pursuing the right actions. Arguable, a good person performs the right actions (Rachels 1993, p. 159 ff.).

According to Foot (1978, pp. 1-18), a moral virtue possesses three features. First, it is a quality that a human being needs to have, "for his own sake and that of his fellows". Second, it is a quality of will, rather than the intellect. Finally, a virtue can function as a correction of either excess or deficiency.

Moral virtues related to food that have been put forward in the literature are hospitality and temperance (Telfer 1996). Hospitality is mainly concerned with our relations to other persons, while temperance primarily concerns our own eating. To see hospitality as a food virtue means that one regards food as something that contributes to being a good person and that helps developing a good character. Not least, the act of the meal can be put forward as a situation that can contribute to the development of desired virtues, such as fellowship and solidarity between people. Thereby, hospitality as a virtue is closely related to the above mentioned duty to ensure every person's right to food. It can be interpreted as fulfilling primarily the first two features in Foot's definition of a virtue, namely to be virtues that every person needs to develop and to be qualities of the will (Foot 1978).

Temperance is a classic virtue, discussed already by Aristotle (384-322 BC). The vice (that is, the opposite that should be avoided) is gluttony. Hence, temperance fulfills especially the third criterion for a virtue above as defined by Philippa Foot, namely to function as a capacity to correct a common deficiency or excess in human motivation (Foot 1978; Telfer 1996, p. 113). I argue, that temperance is a relevant virtue in relation to food ethics dilemmas, as it can ensure several values identified above. For example, it can contribute to health, as it prevents us from excessive eating and developing unhealthy obesity. It can also guide us to reduced meat eating, and thereby preserve several values identified for the affected party animals. Further, the virtue of temperance can contribute to preserving the value of sustainability, as it can encourage us to make use of the whole product when we cook and make us avoid throwing away food, and thereby not waste our common resources.

\section{Care}

The ethics of care was developed in the 1980s, mainly in the USA (see e.g. Gilligan 1993; Noddings 2002). Within this tradition, the experience of giving and 
receiving care is regarded as morally valuable. The concept of care is defined both as a practice and as a moral value. Focus is on attending to and meeting the needs of "particular others", for whom we are responsible (Held 2006). Further, care ethics acknowledges persons' interdependence and the fact that we are all embedded in social contexts, characterized by power orders related to factors such as socioeconomy and gender. Hence, the relational aspect is at the fore of this reasoning. Moral care does not only concern those who are close to us, but can embrace people in other parts of the world, as well as animals and the environment (Held 2006).

In food ethics, a care perspective can be highly relevant. It can motivate us to engage for justice and access to food for everybody, both in our own community and in other parts of the world. It can also inspire us to care for future generations as well as for animals and the environment. Thereby, a care ethics perspective can motivate vegetarianism and help preserving values identified for all affected parties discussed above; for animals, in that they should not be exposed to pain, but rather allowed natural behavior; for the nature, in that care for the environment includes work for low emissions of toxins and low levels of $\mathrm{CO}_{2}$, and for producers, who should be allowed safe working conditions and fair salaries, according to this reasoning. Finally, for consumers, in that a caring perspective highlights the value of health and well-being. Further, as relations are so important in care ethics, also the value of the meal can be strengthened by this perspective. Thereby, it can also contribute to the virtue of hospitality, discussed above.

\section{Conclusion}

The analysis has shown that in relation to food several values are at stake for different affected parties. Further, these values can often come into conflict when choices of food are to be made, based on how the food is produced or handled. I argue, that in order to make well-grounded ethical decisions on what to eat, we need to consider different affected parties and the values that are at stake for them. Further, we need to train our ability to weigh values against each other in light of well-established theoretical models within contemporary ethics, such as duties, consequences and virtues. In addition, I have shown how care can be a helpful concept in food ethics dilemmas.

Affected parties in relation to food that were identified in the article are animals, nature, producers and consumers. These four were chosen as they are relevant for both production and consumption of food, and therefore important to consider in a food ethics analysis. Working from a bottom-up perspective, I identified several values that can be at stake in production and consumption of food for each of these parties. For animals, the values discussed were well-being and natural behavior; for nature, low negative impact on the environment and sustainable climate; for producers, central values were fair salaries and safe working conditions; and for consumers, finally, important values were access to food, autonomy, health and food as part of a good life.

The presentation has shown that it is important to consider several values in food ethics and avoid focusing on only one aspect at the time, as genuine value conflicts can otherwise be missed. Rather, a weighing of values from different ethical 
perspectives is needed. My presentation showed how duties, consequences, virtues and care can be useful in such analyses.

I argue, that the presented ethical framework can provide moral guidance to both producers of food and to consumers in a supermarket. Choices for a consumer can, for example, concern whether to buy organic or locally produced vegetables, or to choose between locally produced meat and organic imported meat, or maybe between meat from cows that help keeping the local landscape open or meat substitutes made from imported soya. Such decisions are not easy to make for a consumer, but based on the presented analysis a consumer inclined to make such choices can ask herself:

- What are the affected parties in this situation?

- What values are at stake for these parties and how do they conflict?

- Can the value conflicts be solved by arguing from the perspective of duties, consequences, virtues or care?

Through such thinking, well-grounded ethical decisions on food can be made. However, the responsibility does not lie only on the consumer. We also need brave political decisions, that can reduce factory farming, toxins, transports and emissions, and support local, small-scale and organic food productions. Through such efforts, we might all feel a little bit more secure when we stand in our grocery shop, reflecting over the question: What shall we eat?

Acknowledgments Open access funding provided by Uppsala University.

Open Access This article is licensed under a Creative Commons Attribution 4.0 International License, which permits use, sharing, adaptation, distribution and reproduction in any medium or format, as long as you give appropriate credit to the original author(s) and the source, provide a link to the Creative Commons licence, and indicate if changes were made. The images or other third party material in this article are included in the article's Creative Commons licence, unless indicated otherwise in a credit line to the material. If material is not included in the article's Creative Commons licence and your intended use is not permitted by statutory regulation or exceeds the permitted use, you will need to obtain permission directly from the copyright holder. To view a copy of this licence, visit http://creativecommons.org/licen ses/by/4.0/.

\section{References}

Aristotle. (1980). Nicomachean ethics (trans: Ross, W. D.). Oxford: World's Classics, Oxford University Press.

Beauchamp, T. L., \& Childress, J. F. (2009). Principles of Biomedical Ethics. New York: Oxford University Press.

Coff, C. (2006). The taste for ethics. An ethic of food consumption (trans: Broadbridge, E.). Dordrecht: Springer.

Foot, P. (1978). Virtues and vices. Oxford: Basil Blackwell.

Gilligan, C. (1993). In a different voice. Psychological theory and women's development. Cambridge: Harvard University Press.

Held, V. (2006). The ethics of care. Personal, political and global. Oxford: Oxford University Press.

Höglund, A. T. (2019). Vad ska vi äta? Om mat och etik (What shall we eat? On food and ethics). Stockholm: Appell Förlag.

Kant, I. (1996). The metaphysics of morals. Cambridge: Cambridge University Press. 
Linderholm, K., \& Wikström, L. (2019). Det är en myt att Sverige inte är självförsörjande (It is a myth that Sweden is not self-sufficient). Expressen. https://www.expressen.se/debatt/det-ar-en-myt-att-sveri ge-inte-ar-sjalvforsorjande/. Accessed 4 March 2020.

Lövin, I. (2010). Tyst hav. Jakten på den sista matfisken (Silent sea. The pursuit of the last food fish). Stockholm: Ordfront förlag.

Luther, M. (2015). The table talk of martin Luther. Warsaw: Sagwan Press.

Mepham, B. (1996). Ethical analysis of food biotechnologies: An evaluative framework. In B. Mepham (Ed.), Food ethics (pp. 101-119). London: Routledge.

Noddings, N. (2002). Starting at home. Caring and social policy. Berkley: University of California Press.

Pence, G. E. (Ed.). (2002). The ethics of food. A reader for the 21st century. Lanham: Rowman \& Littlefied.

Plato. (1955). The republic (trans: Lee, H. D. P.). London: Penguin Books.

Rachels, J. (1993). The elements of moral philosophy (2nd ed.). New York: McGraw-Hill Inc.

Röcklinsberg, H. (2006). Consent and consensus in policies related to food - five core values. Journal of Agricultural and Environmental Ethics, 19, 285-299.

Röös, E. (2012). Mat-klimatlistan, Version 1.0. (The food climate list). Report 040, Sveriges Lantbruksuniversitet, Uppsala.

Ryder, R. D. (2001). Painism. A modern morality. Danville: Open Gate Press.

Segerdahl, P. (2009). Djuren i kulturen: hur naturligt kan våra husdjur leva? (The animals in the culture. How natural can lifestock live?). Göteborg: Daidalos.

Singer, P. (2002). Animal liberalism and vegetarianism. In I. Pence \& E. Gregory (Eds.), The ethics offood. A reader for the 21st century (pp. 26-50). Lanham: Rowman \& Littlefield.

Singer, P., \& Mason, J. (2007). The ethics of what we eat. Why our food choices matter. Emmaus: Rodale Press.

Telfer, E. (1996). Food for thought. Philosophy and food. London: Routledge.

Tellström, R. (2015). Hunger och törst. Svensk måltidshistoria. Från överlevnad till statusmarkör. (Hunger and thirst. A Swedish history of the meal. From survival to status marker). Stockholm: Forum.

Zwart, H. (2000). A short history of food ethics. Journal of Agricultural and Environmental Ethics, 12, 113-126.

Publisher's Note Springer Nature remains neutral with regard to jurisdictional claims in published maps and institutional affiliations. 